\title{
HOW GREEN WAS MY VALLEY: THE CRITIQUE OF THE PICTURESQUE BY IRISH AND GALICIAN WOMEN POETS
}

MANUELA PALACIOS GONZÁLEZ

University of Santiago de Compostela

Since the 1970s there has been a growing interpenetration of both ecology and feminism which has been accompanied by a parallel increase in environmental literature written by women. ${ }^{1}$ In this paper I intend to show how these recent cultural and literary changes and innovations have brought about a critique of the traditional canon of nature writing. Although the literary canon is never a monolithic formation, it has, of old, been predominantly constructed as male; nevertheless, the last three decades have seen the accession of numerous women writers to, among other literatures, the Irish and Galician ones, so there is an evident coalition of forces and interests along gender lines that deserves analysis from the perspective of ecocriticism. Since Françoise d'Eaubonne introduced the term ecoféminisme in France in the 1970s, this movement for social change has highlighted the connection between the exploitation of nature and the oppression of women. ${ }^{2}$ Parallelisms have also been identified between the marginalization of women's writing and that of environmental writing. Therefore, it is not surprising that an important component of the struggle for the liberation of women should concern itself with the preservation of the environment as well.

Recent developments of ecofeminism have questioned the misleading simplicity of the opposition male/female and have introduced in the debates

1. GAARD, Gretta and Patrick D. Murphy (eds.): «Introduction», in Ecofeminist Literary Criticism: Theory, Interpretation, Pedagogy, Urbana \& Chicago, University of Illinois Press, 1998, p. 5.

2. Starhawk: «Power, Authority, and Mystery: Ecofeminism and Earth-Based Spirituality», in Irene Diamond \& Gloria Fernan Orenstein (eds.): Reweaving the World: The Emergence of Ecofeminism, San Francisco, Sierra Club Books, 1990, pp. 73-86. The link woman-nature has provoked dismissals of ecofeminism as an essentialist project. However, ecofeminism actually believes in the interconnectedness of all living beings. See Gates, Barbara T.: "A Root of Ecofemism: Ecoféminisme», in Greta Gaard \& Patrick D. Murphy (eds.): Op.cit., pp. 15-22. 
other parameters such as class, race and colonialism. ${ }^{3}$ Indeed, in the present analysis of Irish and Galician women poets' critique of the Picturesque I have found that the notions of class, religion and nation are deeply interconnected with that of gender in the writers' perceptions of landscapes. Apart from these considerations, ecofeminism has encouraged an important on-going discussion about the alterity of both nature and women that is illuminating for literary criticism. Along this line, though ecology calls our attention to the connection between human and non-human nature, this bond does not mean that human beings can project all their values and needs on non-human nature, because the environment is not a static site of cultural inscription. In fact, several ecofeminist approaches emphasize the relative "otherness» of nature, the constraints that nature poses to our attempts to construe it, and the transformative relations that we must undertake for the benefit of all. ${ }^{4}$ It is my contention in this paper that, contrary to former appropriations of nature by the tradition of the Picturesque, ${ }^{5}$ many Irish and Galician women poets have, of late, been elaborating new discourses that attempt to establish a dialogic relationship with nature, one that explores the bonds and the limitations, the connection and the difference in the rapport between human and non-human nature.

Landscapes of areas with a Celtic background have traditionally been presented as Arcadia both in high literature and in popular culture. ${ }^{6}$ These two poles of the artistic hierarchy are brought together in the recent, Oscar-winning

3. For this insight, which ecofeminism takes from general feminist theory, see De LAURETIS, Teresa: «Eccentric Subjects: Feminist Theory and Historical Consciousness», Feminist Studies, 16 (Spring 1990), pp. 115-150.

4. For the notion of relative difference (the distinction between the "other» and the "another»), and heterarchical relations see MuRPHY, Patrick D.: Literature, Nature, and Other: Ecofeminist Critiques, Albany, State University of New York Press, 1995.

5. The Harrap's Illustrated Dictionary of Art and Artists (Bromley, Clark Robinson, 1990) provides the following definition of the "Picturesque»: "The view of, or aesthetic approach towards, nature that was characteristic of much British art in the later 18th and 19th centuries [...] Uvedale Price's important early manifesto of the Picturesque, An Essay on the Picturesque, as Compared with the Sublime and the Beautiful (1794) [...] Accordingly such things as Gothic architecture, peasant huts and the un-Italianate scenery of the Lake District were considered "picturesque» [...] In a broader sense, it was a symptom of the rise of Romanticism». Although I sometimes use the term "pastoral» as a synonym of "picturesque» in this paper, I have predominantly opted for the latter term because it is related to the art of landscape design, i.e. a very active intervention of human aesthetics in the natural environment, whereas "pastoral» usually refers to the literary representation. Besides, as the definition above shows, the Picturesque has its origins in the Romantic movement, which suits my choice of writers with a late romantic perception of nature as those who perpetuate the Picturesque tradition. «Pastoral», however, has its roots in classical Greek and Roman literatures. For an introduction to the the pastoral genre see GIFFORD, Terry: Pastoral, London, Routledge, 1999.

6. The title of this paper borrows its initial sentence from the film by John Ford which presents the descent of a Welsh valley from pristine paradise to despoiled coal mining place. The past tense in the title reveals the nostalgia for the lost paradise. ForD, John: How Green Was My Valley, USA, Twentieth Century Fox, 1941. Another film that deals with the topic of a fantasy bucolic Celtic setting is Brigadoon, by Vicente Minnelli, which presents two American hunters who, lost in the highlands of Scotland, stumble upon an idyllic imaginary village that charms them. MinnelLI, Vicente: Brigadoon, USA, Metro Godwyn-Mayer, 1954. 
film Million Dollar Baby (2004), directed by Clint Eastwood. In this scrutiny of the treacherous world of boxing there are several conspicuous references to John Ford's The Quiet Man (1952), the link between the two films being the imaginary Irish Arcadia that the boxers cling to as their last opportunity for salvation.7 Both Million Dollar Baby and The Quiet Man make use of a literary allusion that is crucial to understand the impact of the Picturesque on longstanding perceptions of Celtic landscapes. The leading characters of both films, in their yearning for evasion and peace, recite the poem "The Lake Isle of Innisfree» (1888) by W.B. Yeats (1865-1939), the first stanza of which runs as follows:

"I will arise and go now, and go to Innisfree,

And a small cabin build there, of clay and wattles made:

Nine bean-rows will I have there, a hive for the honey-bee,

And live alone in the bee-loud glade» ${ }^{8}$.

Yeats's early poetry has been considered as a late romantic celebration of Irish landscapes, above all of the regions of the West (Sligo) and Galway (Coole Park and Thoor Ballylee). ${ }^{9}$ In the lines above quoted we perceive the longing for the simplicity of rural life, bountiful nature and isolation from other human beings. In the rest of the poem the poetic persona expresses his desire to merge with nature, its sounds and colours. This fusion with nature might initially sound like the goal of any ecology-conscious approach, but, as I will soon try to show, ecofeminism actually proposes some desirable limitations in our connection with nature. The rural landscape in Yeats's poem is presented as a peaceful one that contrasts with the urban space that the speaker is forced to inhabit: "While I stand on the roadways, or on the pavements grey». Finally, the poem draws our attention to the fact that this space is only imagined, though admittedly in a very vivid way, and not a direct description of any real place: «I hear it in the deep heart's core».

It is important that we should be attentive to any signals of detachment between the speaker and the space he conjures up because one of the tenets of ecofeminism is that canonical nature writing does not sufficiently acknowledge that relative difference or alterity of landscape with regard to the poetic persona..$^{10}$ Of course, one poem alone cannot account for the whole canon, but limitations of space require the focus on a text that may be paradigmatic

7. EASTwood, Clint: Million Dollar Baby, USA, Warner Bros., 2004. Ford, John: The Quiet Man, USA, Republic Pictures, 1952.

8. Yeats, W.B.: Collected Poems, London, Picador Classics, 1990, p. 44.

9. Oliveira Da Silva Mcneill, Patricia: "'Heimlich' and 'unheimlich': Landscape in the PostSymbolist Poems of W.B. Yeats and Fernando Pessoa», in J.F. Fernández Sánchez and M. E. Jaime de Pablos (eds.): Irish Landscapes, Almería, Servicio de Publicaciones de la Universidad de Almería, 2003, pp. 243-250.

10. See Donovan, Josephine: «Ecofeminist Literary Criticism: Reading the Orange», in Greta Gaard \& Patrick D. Murphy (eds.): Op. cit., pp. 74-96. 
and influential. ${ }^{11}$ The speaker in this poem is away from the natural setting he describes but his attitude is one of total identification with the place. In fact, one misses a certain acknowledgement of the speaker's position as an outsider, of his noninhabitory and visitational status. Stephen Regan remarks that the poem abounds in syllabic measures and stresses of Gaelic poetry. ${ }^{12}$ However, the verse is written in English. Actually, Regan informs us, even the name of the place "Innisfree» has an evocation of freedom that is not contained in the Gaelic toponym «Inis Fraoigh», which evidences the speaker's alienation from this rural landscape as well as the strategies of manipulation involved in any act of appropriation. Yeats claimed that he had conceived this poem while walking through Fleet Street in London and, we might conclude, the result was a piece of nostalgia for a paradise that had been lost and needed to be recovered. However, as I would like to maintain, this bucolic landscape may have never existed, it may have been only the imaginary effect of his desire to belong to an Irish nation from which his position as a privileged member of the Anglo-Irish community estranged him. Again, Regan's observation that the first line of the poem recalls the Protestant ethics of duty and responsibility in its echo of Luke's Gospel (15:18) in the King James Bible - «I will arise and go to my father»- stresses the notion of displacement and alienation from a country with a Catholic majority. Yeats's idealized representation of Irish landscape might then be understood as a strategy for identification with a nation that resists him, what Declan Kiberd calls the "recourse to geography»: "The classic strategy of the Irish Protestant imagination, estranged from community yet anxious to identify itself with the new patriotic sentiment».13

If W.B. Yeats's poem about Innisfree can be considered to be a pervasive paradigm of the Irish Picturesque, Galicia boasts another male intellectual whose work is a staple of research on local landscape, Celticism and the shared identity of Atlantic communities. Ramón Otero Pedrayo (1888-1976) was a member of the Generation "Nós» (ourselves) whose name was meant to echo the meaning of Sinn Fein (ourselves alone), although the cultural and political project of these Galician nationalists did not envisage the resort to violence to achieve their goals. The Generation Nós established links of brotherhood with other Atlantic communities on the basis of some shared features: an alleged Celtic origin and an Atlantic civilization to be opposed to the classicism of the Greek and Roman empires. These Galician intellectuals identified seven Celtic

11. Terry Gifford gives us an introductory survey of the anti-pastoral tradition, i.e. of the literary texts that repudiate the idealization of the countryside. GIFFORD, Terry: Pastoral, op. cit., pp. 116-145. One should take heed of Gifford's warning that the pastoral is not necessarily a feature of a period, or of a writer, but that one single poem may contain both pastoral and antipastoral passages. As for the impact of the anti-pastoral, I believe that it has traditionally had a peripheral presence in the canon and that its echo in popular culture has been scarce.

12. Regan, Stephen (ed.): "Introduction», in Irish Writing: An Anthology of Irish Literature in English 1789-1939, Oxford, Oxford U.P., 2004, pp. xiii-xxxix.

13. KiberD, Declan: "Yeats, Childhood and Exile» in Paul Hyland \& Neil Sammells (eds.): Irish Writing: Exile and Subversion, Basingstoke, Macmillan, 1991, pp. 126-145. 
nations: the Scottish Highlands, the isle of Man, Ireland, Wales, Cornwall, Brittany and Galicia. ${ }^{14}$

According to María Cuquejo, Otero Pedrayo's idea of landscape constitutes the basis for his nationalist doctrine: he links the Galician land to the Celtic race, which results in the national spirit (Volkgeist) and in the conception of Galicia as a nation..$^{15}$ This political appropriation of landscape should come as no surprise since, according to D.W. Meinig, «every mature nation has its symbolic landscapes». ${ }^{16}$ However, this strategy of appropriation runs counter to ecofeminist proposals of respect for the alterity of nature and for its difference from our cultural constructs. In fact, Donna Haraway has noted that ecofeminism underlines the agency of nature in knowledge as opposed to those master discourses that present landscape merely as a resource to be mapped and appropriated. ${ }^{17}$ Like W.B. Yeats, Otero Pedrayo objects to the changes introduced in the rural world by the forces of modernization (the bourgeoisie and the market) and both look back to pre-industrial social structures for the preservation of the national essence. These beliefs might have a certain resemblance to the resistance, on the part of present-day ecofeminism, to the damaging effects of some types of technological progress and to the reification -the simplification of natural life to the inorganic- for the convenience of market society, were it not for the hierarchical social structure championed by Yeats and Otero Pedrayo. ${ }^{18}$ While considering peasants, sailors and villagers as fundamental components in the articulation of the nation, the Galician intellectual defends the roles of the Church and the nobility in the leadership of the community. ${ }^{19}$ Both Yeats and Otero Pedrayo envisage a harmonious social hierarchy that is allegedly accepted by all its members, and both writers resent the role of the middle class in the transformation of this feudal social order. Their notion of landscape is therefore deeply marked by a nostalgia for a supposedly conflict-free past and a hostility for contemporary changes. In spite

14. Palacios González, Manuela \& Carmen Ríos Fernández: «Galician and Irish Landscapes in the 1920s: New Hopes for the Regeneration of Atlantic Communities», in J. F. Fernández Sánchez \& M.E. Jaime de Pablos (eds.): Op. cit., pp. 103-109. In this article, C. Ríos and I analyse the contacts between the Galician male intellectuals of the Generation Nós and the Irish cultural and political nationalist project, contacts which were made on the basis of the alleged bonds among the seven Celtic nations and the brotherhood of the Atlantic communities.

15. Cuquejo, María: «Introducción», in Ramón Otero Pedrayo: Sereno e grave gozo. Ensaios sobre a paisaxe, Vigo, Galaxia, 1999, pp. 7-31.

16. MeInIG, D.W.: «Symbolic landscapes. Some idealizations of American communities», in D. W. Meinig (ed.): The Interpretation of Ordinary Landscapes, Oxford, Oxford U.P., 1979, pp. 164-192.

17. HarawaY, Donna J.: Simians, Cyborgs, and Women: The Reinvention of Nature, New York, Routledge, 1991, p. 199.

18. Ynestra King has identified certain links between ecofeminism and radical or social ideologies when claiming the antihierarchical practice of ecofeminism and its resistance to the homogenization produced by mass consumer markets, for which all natural resources are just commodities. See KInG, Ynestra: "The Ecology of Feminism and the Feminism of Ecology», in Judith Plant (ed.): Healing the Wounds: The Promise of Ecofeminism, Philadelphia, New Society Publishers, 1989, pp. 18-28.

19. Cuquejo, María: «Introducción», op. cit. p. 13. 
of Otero Pedrayo's broad technical knowledge of Galician geography, Ríos Panisse maintains that his accounts are informed by a romantic epistemology. ${ }^{20}$ This may initially look like a contradiction, but as a matter of fact most notions of landscape combine the geographical and material with the cultural. Along this line, W.J.T. Mitchell provides the following definition of landscape:

«Landscape [...] is itself a physical and multisensory medium (earth, stone, vegetation, water, sky, sound and silence, light and darkness, etc.) in which cultural meanings and values are encoded, whether they are put there by the physical transformation of place in landscape gardening and architecture, or found in a place formed, as we say, 'by nature' [...] Landscape is [...] embedded in a tradition of cultural signification and communication, a body of symbolic forms capable of being invoked and reshaped to express meaning and values». ${ }^{21}$

Otero Pedrayo's pantheistic conception of landscape shows the Galician sailors searching for prophecies in the sky, the moonlight creating fantastic monsters and wintry fears, and the granite stone combining masculine and feminine elements together with a magic dimension. The peasant feels an absolute identification with his land, and his work is ruled by the seasons -Otero Pedrayo tends to speak of land property and agricultural work as being exclusively in male hands. The rural village is, for this writer, the last reservoir of Galician identity, culture and tradition, a symbol of the values that are disappearing in the urban and industrial societies. ${ }^{22}$ Interestingly enough, A. Tinniswood has identified the appropriation of the hamlet as "a tour de force of Picturesque theory and the romantic idealization of country living». ${ }^{23}$ I concur with Richard Muir that the fact that the idyllic village may be an illusory image does not detract from its influence as a powerful symbol of durability, timelessness and stability. ${ }^{24}$ As a matter of fact, this paper attempts to expose the way in which imaginary constructions, like literary representations of landscape, have a potency that allows them to persist even when there is evidence that the physical and cultural conditions have changed.

Some tentative conclusions of the former analysis of two of the most influential artificers of the Celtic landscape in the twentieth century are that Irish and Galician rural spaces are often presented in a nostalgic way that fits the ideology behind the Picturesque. These idealised, romantic perceptions of landscape are informed by the ideals of nationalism, which locate the national

20. Ríos Panisse, María do Carme: "A paisaxe en Otero Pedrayo», en Anxo Tarrío (coord.): Actas do Simposio Internacional Otero Pedrayo no panorama literario do século XX, Santiago de Compostela, Consello da Cultura Galega, 1990, pp. 87-127.

21. Mitchell, W.J.T.: «Imperial landscape», in W.J.T. Mitchell (ed.): Landscape and Power, Chicago, Chicago U.P., 1994, p. 14.

22. For Otero Pedrayo's elaboration of his ideas about the Galician landscape, see his essays «Ensaio sobre a paisaxe galega", "Ensaios acerca do estilo da paisaxe», "Sobre a aldea» and "A aldea galega no seu decorrer histórico» in Ramón Otero Pedrayo: Op. cit.

23. Tinniswood, A.: Life in the English Country Cottage, London, Weidenfeld \& Nicolson, 1995, p. 109.

24. MuIR, Richard: Approaches to Landscape, London, Macmillan, 1999, p. 139. 
essence in the rural world even though this political discourse is most likely to be produced by members of the urban middle class. The bucolic representations seem to forge an obstinate discourse of permanence and belonging in the face of evident signals of change and estrangement. Actually, the political appropriations that we find in these writers' perception of nature contravene ecofeminist claims for the respect for the alterity of the environment. The prodigal Arcadia that results from these representations purposefully ignores the hardship of labour conditions, the conflicts within the social hierarchy and the role of women in the shaping of the landscape. In addition to this, the fantastic and magical dimensions of the Irish Literary Revival and of Otero Pedrayo's configuration of landscape may function as compensatory myths that provide irrational and mystifying accounts for what might otherwise be explained in terms of material conditions.

In the last thirty years both the Irish and Galician literatures have undergone a radical transformation due to the conspicuous incorporation of women writers. This salutary phenomenon may be partly explained by women's access to third level education as well as by the improvements in economic conditions and the gradual emancipation of women. Both in Ireland and Galicia, many women writers have opted for poetry as their means of expression, although this circumstance has been more striking in Galicia, where the predominance of women poets over narrative, drama or essay female writers is overwhelming. The reasons for this connection between gender and genre remain to be fully explored, but what seems to be evident is the transformation that the literary tradition has been undergoing. ${ }^{25}$ By writing poetry, women have become the speaking subjects of their texts and not merely the objects of male recreations of femininity. With their participation in the literary system, women poets have inscribed their interests, experience and values in a predominantly male poetic tradition. The innovative charge of their peripheral perspectives has destabilized the centres of cultural power and has forced a reconsideration of former literary conventions. ${ }^{26}$ It is in this context of challenge to longstanding

25. One possible reason for Galician women poets' major preference for poetry may be strategic, as the group consciousness is supportive of its members, it allows for organized cultural and literary planning and it contributes to the visibility and institutionalization of the writers' production. Therefore, given a female literary model like Rosalía de Castro and a small nucleus of feminist activism around literary journals, other female writers may have chosen to join their forces for the generation of new poetic models that will renovate the canon. Besides, the instability of the Galician literary system, as opposed to other more fixed and rigid ones, may favour a certain flexibility and the access to a central position of what are otherwise seen as peripheral genders and genres. See GonzÁlez FernándeZ, Helena: «Literatura galega de muller, unha visión sistémica», Anuario de Estudios Literarios Galegos 1999, (2001), pp. 41-67.

26. For an analysis of the effects of the accession of women to the Irish poetic tradition see the following: Bourke, Angela et al. (eds.): The Field Day Anthology of Irish Writing, Vol. 5, New York, New York U.P., 2002. Boyle-Haberstroth, Patricia: Women Creating Women. Contemporary Irish Women Poets, Syracuse, New York, Syracuse U.P., 1996. González ARIAS, Luz Mar: Otra Irlanda. La estética postnacionalista de poetas y artistas irlandesas contemporáneas, Oviedo, Servicio de Publicaciones de la Universidad de Oviedo, 2000. González Arias, Luz Mar: Cuerpo, mito y 
perceptions of poetic matters that I would like to consider the current critique of the Picturesque that is being implemented by contemporary women poets in Ireland and Galicia.

Eavan Boland, an Irish poet who enjoys a wide recognition in Ireland and has received a considerable international echo, is responsible for a stimulating debate about the position of women in the Irish poetic tradition. Interestingly enough, her objections to traditional representations of women in the poetry of her country have at one time been related to the figure of the peasant woman and the failure of most former poetry to deal with her challenging complexity. Her essay "A Kind of Scar: The Woman Poet in a National Tradition" (1989) begins with a poem that Boland writes after meeting the Achill woman: ${ }^{27}$

«She pushed the hair out of her eyes with

her free hand and put the bucket down".

The poetic persona, who identifies herself with a student at Trinity -in a straightforward autobiographical gesture- explicitly acknowledges the class and cultural difference between herself and the peasant woman. This encounter with the "other» provokes the speaker's sudden realization that the literary tradition has been blind to this woman's life and history:

«and took down my book and opened it and failed to comprehend

the harmonies of servitude, the grace music gives to flattery and language borrows from ambition».

I would like to suggest that the first step in the critique of the Picturesque is the observer's awareness of her estrangement from the place and the people she is representing, rather than pretending, as Yeats and Otero Pedrayo seemed to do, that there is no such gap or that this fracture is of no consequence. This apprehension of difference need not result in alienation, for there remains the possibility of being "another», of recognising the differences and the similarities in our relationship with the environment. In her essay, Eavan Boland takes issue with the Irish poetic tradition which, in its attempt to construe the nation, has turned the female figure into a sign, into a piece of rhetoric, while at the same time failing to record "the anguish and power of that woman's gesture on Achill, with its suggestive hinterland of pain». ${ }^{28}$ In the attention she pays to the woman's poor clothes and her hands «blushing with cold»" ${ }^{29}$, Boland shows her

teoria feminista: re/visiones de Eva en autoras irlandesas contemporáneas, Oviedo, KRK, 1997. As for the study of the incorporation of women writers in the Galician literary system, see BLANCO, Carmen: Literatura galega da muller, Vigo, Xerais, 1991. GonZÁlez Fernández, Helena: «Literatura galega de muller, unha visión sistémica", op.cit.

27. Boland, Eavan: "A Kind of Scar. The Woman Poet in a National Tradition» in Eavan Boland et al.: A Dozen Lips, Dublin, Attic Press, 1994, pp. 72-92.

28. Ibid., p. 76.

29. Ibid., p. 73. 
concern with social deprivation, while, as Stephen Copley and Peter Garside maintain, "the Picturesque translates the political and the social into the decorative». ${ }^{30}$ As opposed to the effacement of politics and history implemented by the Picturesque, Boland proposes that poetry should engage in the analysis of defeat and loss: "The coffin ships, the soup queues, those desperate villagers at the shoreline ${ }^{31}$. The literary representation of bucolic places has most often turned rural spaces into the opposite of what human life really is, with its privations and labours. Suzanne Said, for instance, sees the bucolic places in the Greek and Latin tradition as a "utopia» both in the sense of ou-topos (place of nowhere) and eu-topos (place of happiness). ${ }^{32}$ For Saï, the bucolic landscape is an artificial paradise, a sweet retreat which opposes itself not just to the city but also to the peasants' work. The only hardship she observes in classical bucolic poetry is that about the difficulties of poetic creation -and this brings into mind poems like Yeats's "The Wild Swans at Coole». As for Otero Pedrayo, his essays on Galician landscape do take into consideration the peasants' work in each season of the year, but he tends to "naturalize» this agricultural work and present it as a source of happiness and fulfilment, which is at best a partial interpretation of the rural conditions of labour.

Eavan Boland is specially critical with the figure of the "peasant poet» and makes W.B. Yeats partly responsible for the promotion of this stereotype. When discussing her encounter with Padraic Column, she regrets his failure to record the "barbaric griefs of the nineteenth century»: "All that heritage which should have been his - rage robbed of language, suffering denied its dignitysomehow eluded him ${ }^{33}$. Like women, peasants had been oversimplified and falsified by the poetic tradition. Therefore, like women poets, the "peasant poet" should seize the opportunity to shift from the position of rhetorical image to that of author. They all should take advantage of the authority and power that go with authorship to challenge the traditional mystifications of femininity and peasantry. The problem with Padraic Column, according to Boland, was that:

«He wrote Irish poetry as if he were still the object of it. He wrote with the passivity and simplification of his own reflection looking back at him from poems, plays and novels in which the so-called Irish peasant was a son of the earth, a cipher of the national cause ${ }^{34}$.

We may conclude that Eavan Boland's contribution to the critique of the Picturesque contains several guidelines that are of import to feminist theory and practice. To start with, she inscribes the figure of the female peasant in the

30. Copley, Stephen and Peter Garside (eds.): The Politics of the Picturesque. Literature, Landscape and Aesthetics since 1770, Cambridge, Cambridge U.P., 1994, p. 6.

31. Boland, Eavan: Op. cit., p. 77.

32. SAÏD, Suzanne: «Le paysage des Idylles bucoliques» in Michel Collot (dir.): Les enjeux du paysage, Bruxelles, OUSIA, 1997, pp. 26-27.

33. BolAnd, Eavan: Op. cit., p. 83.

34. Ibid., p. 84. 
representation of the rural landscape, thus making her experience visible, but instead of presenting her as a coquettish shepherdess -as much bucolic poetry does- Boland's Achill woman exposes the privations of the rural world and the inequalities within the Irish society. Next, Boland turns this peasant woman into the force that provokes a critique of the former literary tradition so, instead of being a mere object of representation, this female figure becomes a challenge to the ideological interests behind much literary discourse. With her dignified -not the least folkloric- presence, the Achill woman denounces how literature as an institution has of old taken sides with other dominant discourses that oppress, manipulate and obliterate the disempowered classes. Finally, in consonance with the claims of ecofeminism, Boland establishes a parallelism between women and the peasantry with regard to the falsification that literature has made of their experience -paradoxically enough sometimes for the benefit of discourses on national liberation- and urges both groups to produce their own discourses and articulate their own experiences. ${ }^{35}$ This insistence on experience and reality actually establishes an opposition not just with the artificiality of literary conventions but also with extreme postmodern views that reduce the world to discourse. Of course, the pursuit of a representation of reality in the literary text that is not mediated by our cultural patterns is a chimera -an illusion not unlike the pastoral conventions. This tension between standpoint claims like Boland's -her belief that members of an oppressed group can and should produce alternative discourses about their experience- and the idea that nature may be a discursive product has been aptly negotiated by critics like $N$. Katherine Hayles, with her notion of "constrained constructivism", a view that acknowledges the constraints that nature imposes on any epistemological effort, and by SueEllen Campbell, who suggests that we could include nature as one of those forces outside ourselves which actually construct us. ${ }^{36} \mathrm{~A}$ considerable number of ecocritics refuse to restrict the role of nature to that of object of our attention, whether for protection or exploitation, and prefer

35. Contrary to what these conclusions may suggest, Eavan Boland is no "peasant poet» herself. In fact, she has been accused of ventriloquism for her attempt to speak for both colonizers and colonized. See Ní FHRighil, Ríóna: «Eavan Boland and Nuala Ní Dhomhnaill Revise the Landscape» in J.F. Fernández Sánchez \& M.E. Jaime de Pablos (eds.): Op. cit., pp. 231-241. Besides, in her effort to articulate her own experience, Boland has limited much of her poetry to the representation of the suburban middle-class. Though these objections must be born in mind, I do not think they invalidate Boland's critique of the Picturesque. Other critics have identified a radical shift in Boland's poetry from the early pastoralism in her book New Territory (1967) to later reformulations of landscape from the 80s onwards that have deconstructed the romantic idea of Ireland. See Villar Argáiz, María Pilar: "The Perception of Landscape in Eavan Boland's Poetry: From a 'Romantic' Pilgrimage to a World of Constellations and Suburbs» in J.F. Fernández Sánchez \& M.E. Jaime de Pablos (eds.): Op. cit., pp. 265-275.

36. HaYles, N. Katherine: "Searching for Common Ground", in Michael E. Soulé \& Gary Lease (eds.): Reinventing Nature? Responses to Postmodern Deconstruction, Washington D.C., Island Press, 1995, pp. 98-104. CAmpBell, Sue Ellen: "The Land and Language of Desire: Where Deep Ecology and Poststructuralism Meet», Western American Literature, 24 (Nov. 1989), pp. 199-211. 
to define the human and non-human relationship as one between mutually speaking subjects. ${ }^{37}$

Boland is not alone among contemporary Irish women poets in her interrogation of the tradition of the Picturesque. Anne Le Marquand Hartigan also focuses on the female figure to expose the unequal power relations and the sexual division of labour. In "Land", a section from her longer poem Now is a Moveable Feast (1991), she shows the workings of patriarchy in the rural world: "And thou shalt be under thy husband's power"». ${ }^{38}$ This Biblical injunction exemplifies the role of the Church in the contrivance of unjust gender relations. Hartigan problematizes the traditional simplification in the identification of woman and land for either colonialist or nationalist purposes -where the male politician is the eager suitor or the martyr son of the passive female nation- by denouncing how patriarchy views both women and land as properties to be exploited and as mirrors of male dominance:

"The land, must prove,

must know, must pass, from hand to hand, from Father to Son,

the need, in the cut of the plough,

the yearn

for seed,

the ache

for increase

to cleave

penetrate

and grow,

'And he shall have dominion over thee'»

Mary Dorcey is another Irish poet who makes the female figure the protagonist of her unsentimental description of rural life in "Woman in a Normandy Field». ${ }^{39}$ The woman is now the worker, the one that shapes the land and is shaped by it. Dorcey does not speak of victimization here, just of hard work, discipline and tenacity, which results in a realistic dignification of the peasant woman's labour:

«Then slowly her knees bent to ground once more

and with deliberate hands

she began the season's first task.»

37. For the distinction between "object of attention» and «mutually speaking subjects» see the first two chapters in Murphy, Patrick D.: Literature, Nature, and Other: Ecofeminist Critiques, op.cit.

38. Hartigan, Anne Le Marquand: «Land», in Now is a Moveable Feast, Bridge Mills, Galway, Salmon Publishing, 1991, pp. 21-30.

39. Dorcey, Mary: "Woman in a Normandy Field» (1982), in Moving into the Space Cleared by Our Mothers, Bridge Mills, Galway, Salmon Publishing, 1991, p. 86. 
Galician women poets also elaborate on the experiential, creative and human aspects of their relationship with landscape. In fact, many of them grew up in rural areas and therefore have a first-hand acquaintance with life in the country. In many cases, their rural experience was limited to the period of childhood, while subsequent school and work drove them away to the city. Their poetic portrayal of the rural space does not seem to rise merely out of nostalgia but of the need to construe their subjectivity and to understand the role of country life in their identity. These memories of childhood do not present an Edenic garden but show a deep awareness of the satisfactions and the difficulties, the fulfilment and the privation of life and work in rural areas. The fact that their account of the rural experience is an autobiographical first-person one reduces the distance between the subject and the object of representation that we found, for instance, in writers like Eavan Boland. Nevertheless, these Galician women poets tend to acknowledge the presence of many other gulfs that affect their vision: language, access to education, abandonment of agricultural work, urban experience, etc. They problematize the epistemic privilege, i.e. the belief that their first-hand experience may provide them with the critical knowledge to understand their oppression. Their protagonists are not triumphant ecofeminist heroines and, rather than epiphanies, what they experience is the hardship in the articulation of their values. In spite of the supposed privileges that they now enjoy, these poets often attempt to challenge the logic of inferiorization that was imposed on them as children: the fact that living in the country and speaking Galician made them inferior to those who lived in cities and spoke Spanish. Much poetry by contemporary women, then, has engaged in a valorization of a previously denigrated identity.

Luz Pichel is a Galician poet who has lived in Madrid for over thirty years. She writes her poetry in Spanish and has her work published by institutions from all over Spain. Her recent collection of poems La marca de los potros (2004) has no toponymical references to Galician places, no clear allusions that allow us to locate the poems in the Galician landscape, but in her presentations and discussions of this book Pichel recurrently connects her poems with her rural experience as a child in a tiny Galician village. I have chosen this collection because it clearly illustrates the critique of the Picturesque that I present as the main hypothesis of this article. Pichel's poetry registers the fears, dangers, frustrations, conflicts, fantasies and satisfactions that peasants derive from their contact with nature. She is perceptive to the ways in which people shape landscapes with their fences and to the conflicts over land property that these divisions bring about:

«Reconocer los límites de las propias tierras, Aceptarlos sin pelear con el vecino ${ }^{40}$

40. "To recognize the limits of our own lands/ to accept them without quarrelling with the neighbour». The translations of Galician poetry into English are mine. PicheL, Luz: La marca de los potros, Huelva, Servicio de Publicaciones de la Diputación de Huelva, 2004, II, p. 14. (The Roman numbers refer to those of the poems in this collection). 
These fences are barriers that only boys are allowed to transgress, as the poetic persona cruelly expresses in what constitutes one of the first lessons about gender difference imparted during childhood:

"Así te hundiré.

Te hundiré los rizos dorados en el agua asquerosita de

la alberca.

$[\ldots]$

¡Ale! Para que aprendas a no saltar vallados antes que yo, que soy mayor que tú y te puedo.

Por lista» ${ }^{41}$

The agricultural work is easily ruined by multiple hostile forces ${ }^{42}$ and dangerous storms put the peasant's life at risk ${ }^{43}$. Many are the dangers and the fears, and the temptation is strong to take refuge in discourses about the beauty of nature so as to obliterate the feelings of loss and impotence ${ }^{44}$. The economic relations, the material conditions of production, the peasants' commerce with their products become now dignified topics for poetry ${ }^{45}$; in fact, the responsible cooperation with the land, even if it is in economic terms, is one of the objectives of ecofeminism. ${ }^{46}$ Nature can be either hostile: «la engañosa luna enredándote las piernas» ${ }^{47}$ or vulnerable: "El nido en esa zarza lo pisarán los carros», ${ }^{48}$ but it is no longer a sanctuary, a metaphysical place of safety and retreat where one can transcend the pain of living. The relationship with the land is not merely through perception with an active onlooker and a passive object of the observation. Human and non-human elements have a reality of their own to communicate. Their relationship is dialogical. In fact, the land reacts to the peasants' aggression by leaving its mark on their bodies ${ }^{49}$. Childhood is not a time of wild freedom away from the adults' responsibilities, but a period of apprenticeship with certain obligations -many Galician women poets refer to their early experience of watching over the grazing cows-, few rewards and many punishments ${ }^{50}$.

Galicia has shared with Ireland this agricultural economy that, at moments of crisis, has forced millions of people to emigration. Luz Pichel, like many other Galician people, expresses her gratitude to her brother because he

41. "I'll sink you like this/ I'll sink your golden locks in the foul water of / the reservoir/ [...]/ There it goes! A lesson to stop you from jumping over the fences before I do/ 'cause I am older and stronger than you/ That's what you get for being so clever!» PICHel, Luz: Op. cit., XLIII, p. 61.

42. Ibid., V, p. 17.

43. Ibid., IX, p. 21.

44. Ibid., XII, p. 24.

45. Ibid., XV, pp. 27-28.

46. Vance, Linda: «Ecofeminism and the Politics of Reality», in Greta Gaard (ed.): Ecofeminism, Women, Animals, Nature, Philadelphia, Temple University Press, 1993, pp. 118-145.

47. PICHeL, Luz: Op. cit., XXVI, p. 42, "The deceiving moon tangling up your legs.»

48. Ibid., XXVIII, p. 44, "The nest on that bush will be trampled on by the carts.»

49. Ibid., XXXIV, p. 51, XLIV, p. 62.

50. Ibid., LXVI, p. 85. 
granted her access to education with the money he sent home from America. In her poetry, the poet relates her initiation to writing with her expectations about her brother's presents from foreign lands:

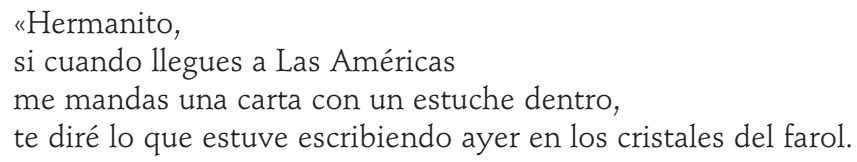

¿Tú no vas a llorar? ${ }^{51}$

Practicioners of pastoral poetry often make use of the figure of the traveller or stranger as the poetic persona who contemplates the bucolic landscape in a clear contrast with the villagers' domesticity, since the latter do not seem to need that capacity to go wherever they please..$^{52}$ Luz Pichel, however, records in her writings the peasants' desire to escape and the fantasies about a more prosperous life elsewhere ${ }^{53}$.

Chus Pato is a poet who uses the Galician language for her literary work -as a matter of fact, the number of women poets from this community who currently write in Galician is considerably more numerous than that of writers in Spanish- and, though the language brings her closer to the rural experience of her childhood, she is conscious about other fractures in her relationship with her ancestors. In opposition to many Picturesque representations of the countryside which are "strangely empty of human presence», ${ }^{4}$ Pato has her poetry inhabited by an abundance of relatives and neighbours: some still living in her family's village, others gone away as emigrants, and finally some who, though dead, have left their imprint on the land and on her memory. Her poem A ponte das poldras (1996) presents her people in the agricultural activities of her region: the men digging the land that will produce the cabbages and the potatoes, the women following the oxen. ${ }^{55}$ The female figure has a special relevance for Pato, not just out of a deeply felt gender bond, but because the

51. Ibid., XXIII, p. 38, «Dear brother/ if when you arrive in the Americas/ you send me a letter with a pen case inside/ I'll tell you what I was writing yesterday on the lamp glass/ Won't you cry?».

52. Oliveira Da Silva Mcneill, Patricia: Op. cit., p. 247.

53. Pichel, Luz: Op. cit., XVI, p. 29.

54. Mutran, Munira H.: "Different Ways to Apprehend Landscape» in J.F. Fernández-Sánchez \& M.E. Jaime de Pablos (eds.): Op. cit., p. 78.

55. I should avow that my choice of Irish and Galician poems has an important anthropocentric component, though not an androcentric one, as the focus of this paper is marked by a materialist approach towards the power relations and conditions of labour in the relationship between human and non-human nature. L. Buell, however, talks about an emerging ecocentric repossession of pastoral that is shifting from the «representation of nature as a theater for human events to representation in the sense of advocacy of nature as a presence for its own sake» (emphasis mine). BuelL, Lawrence: The Environmental Imagination: Thoreau, Nature Writing, and the Formation of American Culture, Cambridge, MA Harvard U.P., 1995, p. 52. Ecofeminism highlights the distinction between things-in-themselves and things-for-us, since what may initially look like a good thing for us may not be so for the ecosystem. 
poet links these women's work to literary creation. This way, Pato destabilizes the opposition culture/nature, which often feminizes nature and equates woman with nature, by showing women as creators of culture and exposing that culture is not radically discontinuous with nature. Nevertheless, as the poetic voice admits, the link with the female ancestors is also necessarily a manifestation of a gap:

«Ao igual que todas as mulleres que me precederon e que encetaron o seu canto nas vendimas ou nas segas, nas luminiscentes e cegadoras senras -como cobra saltarina, como cobra- eu, a primeira entre todas elas que non sei cavar, nin segar, nin vendimar, quixera comunicar lingua, creación, praxe lingüística: ESCRITA» ${ }^{56}$

Lupe Gómez is another Galician poet whose work goes along the line of Eavan Boland's proposal that writers from the rural world should undo the Picturesque simplifications by replacing the stale conventions of the pastoral with new challenging perspectives. In Fisteus era un mundo (2001), Gómez elaborates the memoir that constitutes the basis of her poetic work with regard to her childhood in a rural village. Her account of life in the country responds to the need to valorize a supplement of experience that had been formerly denigrated and, though this valorization may imply a certain idealization of which Gómez is explicitly conscious, her memoir does not omit the privations and the oppresion that are part and parcel of rural life. Her literary production actually analyses the unrelenting process of deculturation of her birthplace, a process that has stripped peasants of the possibility to maintain their customs, language and subsistence agriculture. Gómez's work can be considered as ecofeminist for its position of resistance to dominant culture and for its insistence on the appreciation of difference.

For Lupe Gómez, the bond with the land is not merely metaphysical, as her parents' house had no concrete or tiled floor but just the earthy ground: "Aínda me acordo de cando o chan era a propia terra. Viviamos sumerxidos na terra, no campo". ${ }^{57}$ In spite of this intimate connection, the lands where her family worked were not of their property and the frustrated longing for buying them filled the successive generations alternately with hope and dismay ${ }^{58}$. The animals were not decorative elements of a bucolic picture but almost members of the family. As a child, Gómez felt so close to the cows, when she watched over them, that on one occasion she even attempted to eat some earth ${ }^{59}$. This desire to put oneself in the place of nature, to learn what it may be like to

56. "Just like all the women who preceded me and started their song in the/ grape harvests or while reaping, in the luminescent and blinding corn fields -like a dancing cobra, / like a cobra- I, the first one among them all who cannot dig, or reap, or / harvest the grapes, I would like to communicate language, creation, lingüistic praxis: WRITING». PATO, Chus: A ponte das poldras, Santiago de Compostela, Noitarenga, 1996, p. 25.

57. "I still remember when the floor was the land itself. We lived submerged in the ground, in the fields». Gómez, Lupe: Fisteus era un mundo, Vigo, A Nosa Terra, 2001, p. 18.

58. Ibid., p. 64.

59. Ibid., p. 31. 
be non-human, to see nature as a locus of knowledge, is one of the central recommendations of current ecofeminism. These cows will provide the future writer with the imagery to refer to her relation with the Galician language: «Eu sempre falei galego con naturalidade. Con naturalidade e con forza, coa forza dunha vaca parindo un becerro". ${ }^{60}$ Also, contrary to Otero Pedrayo's defence of the leading role of the Church in preindustrial societies, Gómez makes this religious institution responsible for women's aversion to sexuality: "A igrexa rompíache o corpo". ${ }^{61}$ In fact, the Church is seen as the apparatus behind the imbalance in the gender relations. It is actually with regard to the trap of traditional gender roles that Lupe Gómez shows her most incisive criticism of the rural world. Her memoir is thus a literary preservation of rural culture, but one that incorporates the need to change oppressive structures.

In November 2002 Galicia suffered a catastrophe of longlasting consequences for the natural environment and the local economy. The women poets also had their say in the multitudinous reaction to official incompetence and mass media manipulation during the «Prestige crisis» - the oil slick pollution that resulted from the sinking of the oil tanker Prestige. Chus Pato, María Lado, Verónica Martínez Delgado, Helena de Carlos, Xela Arias, Ana Romaní, Emma Pedreira and many others contributed with their poems to the growing awareness about the need for a social change..$^{62}$ In the face of a catastrophe like this one, the discourse of the Picturesque, with its alleged love of nature while it actually turns a blind eye on the causes of its deterioration, should be at best a residual one to be steadily replaced by the alternative and emerging discourse of ecofeminism. New struggles are being waged against the maldevelopment and environmental degradation caused by global capitalism while, simultaneously, they are waged for economic values and programmes based on subsistence and sustainability. ${ }^{63}$

60. «I have always spoken Galician in a natural way. In a natural and vigorous way, with the vigour of a cow calving.» Ibid., p. 92.

61. "The church broke your body.» Ibid., p. 32. Although this paper focuses on landscape as nature, Ynestra King draws our attention to our own bodily nature and to the need for a renewed understanding of our relationship to it. See KING, Ynestra: "The Ecology of Feminism and the Feminism of Ecology», op.cit., p. 20. Contrary to the dualism male-mind/ female-body that constructs the body as inferior and as obstacle to the progress of culture, ecofeminism reveals the body as a locus of knowledge.

62. See the collective edition of texts SempreMar. Cultura contra a burla negra, Santiago de Compostela, Asociación cultural Benito Soto, 2003.

63. GaARD, Greta and Patrick D. Murphy (eds.): «Introduction», op. cit., p. 2. Murphy thinks that it is not merely coincidental that the attacks on cultural diversity (multiculturalism, multilateral international decisions, sexual and religious diversity, etc.) should occur at the same time that Western countries postpone evironmental regulations. Certainly, the homogenization of culture suits the needs of multinational corporations. Murphy also sees an insidious effort on the part of dominant powers to efface the link between our values and their effects on the environment ( $p$. 23). MuRPHY, Patrick D.: "'The Women Are Speaking': Contemporary Literature as Theoretical Critique», in Greta Gaard \& Patrick D. Murphy (eds): Op. cit., pp. 23-48. 


\section{WORKS CITED}

Blanco, Carmen: Literatura galega da muller, Vigo, Xerais, 1991.

BolAnd, Eavan: "A Kind of Scar. The Woman Poet in a National Tradition", in Eavan Boland et al.: A Dozen Lips, Dublin, Attic Press, 1994, pp. 72-92.

Bourke, Angela et al. (eds.): The Field Day Anthology of Irish Writing, Vol. 5, New York, New York U.P., 2002.

Boyle-Haberstroth, Patricia: Women Creating Women. Contemporary Irish Women Poets, Syracuse, New York, Syracuse U.P., 1996.

BuelL, Lawrence: The Environmental Imagination: Thoreau, Nature Writing, and the Formation of American Culture, Cambridge, MA, Harvard U.P., 1995.

Campbell, Sue Ellen: "The Land and Language of Desire: Where Deep Ecology and Poststructuralism Meet», Western American Literature, 24 (Nov. 1989), pp. 199-211.

Copley, Stephen and Peter GARside (eds.): The Politics of the Picturesque. Literature, Landscape and Aesthetics since 1770, Cambridge, Cambridge U.P., 1994.

Cuquejo, María: "Introducción», in Ramón Otero Pedrayo: Sereno e grave gozo. Ensaios sobre a paisaxe, Vigo, Galaxia, 1999, pp. 7-31.

De Lauretis, Teresa: «Eccentric Subjects: Feminist Theory and Historical Consciousness», Feminist Studies, 16 (Spring 1990), pp. 115-150.

Donovan, Josephine: «Ecofeminist Literary Criticism: Reading the Orange», in Greta Gaard \& Patrick D. Murphy (eds.): Ecofeminist Literary Criticism: Theory, Interpretation, Pedagogy, Urbana \& Chicago, University of Illinois Press, 1998, pp. 74-96.

DorCEY, Mary: "Woman in a Normandy Field» (1982), in Moving into the Space Cleared by Our Mothers, Bridge Mills, Galway, Salmon Publishing, 1991, p. 86.

Eastwood, Clint: Million Dollar Baby, USA, Warner Bros., 2004.

Fernández SÁnchez, José Francisco \& $\mathrm{M}^{a}$ Elena Jaime de Pablos (eds.): Irish Landscapes, Almería, Servicio de Publicaciones de la Universidad de Almería, 2003.

Ford, John: How Green Was My Valley, USA, Twentieth Century Fox, 1941.

- The Quiet Man, USA, Republic Pictures, 1952.

GAARD, Gretta and Patrick D. Murphy (eds.): "Introduction", in Ecofeminist Literary Criticism: Theory, Interpretation, Pedagogy, Urbana \& Chicago, University of Illinois Press, 1998, pp. 1-13.

Gates, Barbara T.: "A Root of Ecofemism: Ecoféminisme», in Greta Gaard \& Patrick D. Murphy (eds.): Ecofeminist Literary Criticism: Theory, Interpretation, Pedagogy, Urbana \& Chicago, University of Illinois Press, 1998, pp. 15-22.

GifFord, Terry: Pastoral, London, Routledge, 1999.

Gómez, Lupe: Fisteus era un mundo, Vigo, A Nosa Terra, 2001.

GonzÁlez Arias, Luz Mar: Otra Irlanda. La estética postnacionalista de poetas y artistas irlandesas contemporáneas, Oviedo, Servicio de Publicaciones de la Universidad de Oviedo, 2000.

- Cuerpo, mito y teoría feminista: relvisiones de Eva en autoras irlandesas contemporáneas, Oviedo, KRK, 1997.

GonZÁlez Fernández, Helena: "Literatura galega de muller, unha visión sistémica», Anuario de Estudios Literarios Galegos 1999, (2001), pp. 41-67.

Haraway, Donna J.: Simians, Cyborgs, and Women: The Reinvention of Nature, New York, Routledge, 1991.

Harrap's Illustrated Dictionary of Art and Artists, Bromley, Clark Robinson, 1990.

Hartigan, Anne Le Marquand: "Land», in Now is a Moveable Feast, Bridge Mills, Galway, Salmon Publishing, 1991, pp. 21-30. 
Hayles, N. Katherine: "Searching for Common Ground», in Michael E. Soulé \& Gary Lease (eds.): Reinventing Nature? Responses to Postmodern Deconstruction, Washington D.C., Island Press, 1995, pp. 98-104.

KiberD, Declan: «Yeats, Childhood and Exile» in Paul Hyland \& Neil Sammells (eds.): Irish Writing: Exile and Subversion, Basingstoke, Macmillan, 1991, pp. 126-145.

KING, Ynestra: "The Ecology of Feminism and the Feminism of Ecology", in Judith Plant (ed.): Healing the Wounds: The Promise of Ecofeminism, Philadelphia, New Society Publishers, 1989, pp. 18-28.

MeINIG, D.W.: «Symbolic landscapes. Some idealizations of American communities», in D. W. Meinig (ed.): The Interpretation of Ordinary Landscapes, Oxford, Oxford U.P., 1979, pp. 164-192.

MinnelLI, Vicente: Brigadoon, USA, Metro Godwyn-Mayer, 1954.

Mitchell, W.J.T.: "Imperial landscape», in W.J.T. Mitchell (ed.): Landscape and Power, Chicago, Chicago U.P., 1994, pp. 5-34.

MuIR, Richard: Approaches to Landscape, London, Macmillan, 1999.

MurpHY, Patrick D.: «The Women Are Speaking': Contemporary Literature as Theoretical Critique», in Greta Gaard \& Patrick D. Murphy (eds): Ecofeminist Literary Criticism: Theory, Interpretation, Pedagogy, Urbana \& Chicago, University of Illinois Press, 1998, pp. 23-48.

- Literature, Nature, and Other: Ecofeminist Critiques, Albany, State University of New York Press, 1995.

Mutran, Munira H.: "Different Ways to Apprehend Landscape» in J.F. FernándezSánchez \& M.E. Jaime de Pablos (eds.): Irish Landscapes, Almería, Servicio de Publicaciones de la Universidad de Almería, 2003, pp. 75-79.

Ní Fhrighil, Ríóna: "Eavan Boland and Nuala Ní Dhomhnaill Revise the Landscape» in J.F. Fernández Sánchez \& M.E. Jaime de Pablos (eds.): Irish Landscapes, Almería, Servicio de Publicaciones de la Universidad de Almería, 2003, pp. 231-241.

Oliveira Da Silva Mcneill, Patricia: "'Heimlich' and 'unheimlich': Landscape in the PostSymbolist Poems of W.B. Yeats and Fernando Pessoa», in J.F. Fernández Sánchez and M. E. Jaime de Pablos (eds.): Irish Landscapes, Almería, Servicio de Publicaciones de la Universidad de Almería, 2003, pp. 243-250.

Palacios González, Manuela \& Carmen Ríos Fernández: «Galician and Irish Landscapes in the 1920s: New Hopes for the Regeneration of Atlantic Communities», in J. F. Fernández Sánchez \& M.E. Jaime de Pablos (eds.): Irish Landscapes, Almería, Servicio de Publicaciones de la Universidad de Almería, 2003, pp. 103-109.

PATO, Chus: A ponte das poldras, Santiago de Compostela, Noitarenga, 1996.

Pichel, Luz: La marca de los potros, Huelva, Servicio de Publicaciones de la Diputación de Huelva, 2004.

Regan, Stephen (ed.): "Introduction», in Irish Writing: An Anthology of Irish Literature in English 1789-1939, Oxford, Oxford U.P., 2004, pp. xiii-xxxix.

Ríos Panisse, María do Carme: "A paisaxe en Otero Pedrayo», en Anxo Tarrío (coord.): Actas do Simposio Internacional Otero Pedrayo no panorama literario do século XX, Santiago de Compostela, Consello da Cultura Galega, 1990, pp. 87-127.

SAÏD, Suzanne: "Le paysage des Idylles bucoliques», in Michel Collot (dir.): Les enjeux du paysage, Bruxelles, OUSIA, 1997, pp. 13-31.

STARHAWK: "Power, Authority, and Mystery: Ecofeminism and Earth-Based Spirituality", in Irene Diamond \& Gloria Fernan Orenstein (eds.): Reweaving the World: The Emergence of Ecofeminism, San Francisco, Sierra Club Books, 1990, pp. 73-86.

Tinniswood, A.: Life in the English Country Cottage, London, Weidenfeld \& Nicolson, 1995. 
VANCE, Linda: «Ecofeminism and the Politics of Reality», in Greta Gaard (ed.): Ecofeminism, Women, Animals, Nature, Philadelphia, Temple University Press, 1993, pp. 118-145.

Villar Argáiz, María Pilar: "The Perception of Landscape in Eavan Boland's Poetry: From a 'Romantic' Pilgrimage to a World of Constellations and Suburbs», in J.F. Fernández Sánchez \& M.E. Jaime de Pablos (eds.): Irish Landscapes, Almería, Servicio de Publicaciones de la Universidad de Almería, 2003, pp. 265-275.

V.AA. SempreMar. Cultura contra a burla negra, Santiago de Compostela, Asociación cultural Benito Soto, 2003.

Yeats, W.B.: Collected Poems, London, Picador Classics, 1990. 